\title{
Effects of ensiling on ruminal degradability and intestinal digestibility of Italian rye-grass
}

\author{
J. González ${ }^{\mathrm{a}, *}$, J. Faría-Mármol ${ }^{\mathrm{a}, 1}$, \\ C.A. Rodríguez ${ }^{\text {a }}$ A. Martínez ${ }^{b}$ \\ a Departamento de Producción Animal, Escuela Técnica Superior de Ingenieros Agrónomos, \\ Universidad Politécnica de Madrid, Ciudad Universitaria, 28040 Madrid, Spain \\ b Servicio Regional de Investigación y Desarrollo Agroalimentario (SERIDA), \\ 33300 Villaviciosa (Asturias), Spain
}

Received 3 February 2006; received in revised form 22 August 2006; accepted 28 August 2006

\begin{abstract}
The effective degradability (ED) and the intestinal effective digestibility (IED) of dry matter (DM) and crude protein $(\mathrm{CP})$ of a green Italian rye-grass (GRG) crop and its silage (ERG) were determined using in situ and particle passage techniques on three wethers, cannulated in rumen and duodenum. Two rumen incubations with duplicate bags filled with $3 \mathrm{~g}$ of freeze-dried samples were performed for each feed at times of $0,2,4,8,16,24,48$ and $72 \mathrm{~h}$. On each incubation, one series of bags was used to determine rumen degradation and the other was freeze-dried and pooled for each incubation time. Then two sub-samples $(0.2 \mathrm{~g})$ were incubated into mobile nylon bags through the entire intestine of each animal. The microbial contamination of rumen incubated residues (determined with ${ }^{15} \mathrm{~N}$ techniques) was fitted to an exponential function. The asymptotic values $(m)$ for DM contamination showed that silage particle reached a greater colonisation $(\mathrm{P}=0.006)$ but with a slower rate of microbe accumulation $(\mathrm{P}=0.03)$. Values of $m$ for $\mathrm{CP}$ also showed that the undegradable $\mathrm{CP}$ fraction was mainly of microbial

Abbreviations: $a$, soluble fraction; ADF, acid detergent fibre; ADIN, acid detergent insoluble N; $b$, non-soluble degradable fraction; $\mathrm{CP}$, crude protein; DM, dry matter; $\mathrm{ED}$, effective degradability; $\mathrm{ED}_{\mathrm{p}}$, effective degradability calculated using $k_{\mathrm{p}} ; \mathrm{ED}_{\mathrm{c}, \mathrm{p}}$, effective degradability calculated using $k_{\mathrm{c}}$ and $k_{\mathrm{p}} ; \mathrm{ERG}$, ensiled rye-grass; GRG, green rye-grass; IED, intestinal effective digestibility; $k_{\mathrm{c}}$, rate of particle comminution; $k_{\mathrm{p}}$, outflow rate from the rumen; NDF, neutral detergent fibre; NDIN, neutral detergent insoluble $\mathrm{N} ; r$, undegradable fraction; SAB, solid adherent bacteria; TAA, total analysed amino acids

* Corresponding author. Tel.: +34 915493069; fax: +34 915499763.

E-mail address: javier.gonzalez@upm.es (J. González).

1 Present address: Facultad de Agronomía, Universidad del Zulia, Maracaibo, Venezuela.
\end{abstract}


origin ( 0.745 and 0.870 for GRG and ERG, respectively). Two different ED estimates were established: $\mathrm{ED}_{\mathrm{p}}$, considering the particle rumen outflow rate $\left(k_{\mathrm{p}}\right)$ of the $\mathrm{ERG}$, and $\mathrm{ED}_{\mathrm{c}, \mathrm{p}}$, considering additionally the fractional rate of conminution and mixing $\left(k_{\mathrm{c}}\right)$ of these particles. Mean values (and S.E.) of both rates were: $0.0497 \pm 0.0113$ and $0.181 \pm 0.0165\left(\mathrm{~h}^{-1}\right)$, respectively. The microbial contamination implied an under-evaluation of $\mathrm{ED}_{\mathrm{p}}$ and $\mathrm{ED}_{\mathrm{c}, \mathrm{p}}$ for $\mathrm{CP}: 12.7$ and $13.5 \%$ in $\mathrm{GRG}$ and 11.0 and $12.4 \%$ in ERG, respectively. These errors were higher for the associated values of undegraded CP. Thus, a proportion of 0.380 and 0.490 in GRG and 0.429 and 0.538 in ERG of these estimates will be really of microbial origin. No differences for $\mathrm{ED}_{\mathrm{p}}$ or $\mathrm{ED}_{\mathrm{c}, \mathrm{p}}$ values were shown between $\mathrm{CP}$ and total analysed amino acids (assumed as representative of true protein). The interference of microbial contamination of feeds in the rumen was also evident in intestinal disappearance values, which showed an irregular and inconsistent evolution with the increase of the rumen residence time. Ensiling reduced the ED and IED of DM as well as the protein undegraded fraction and its IED.

(C) 2006 Elsevier B.V. All rights reserved.

Keywords: Rumen degradation; Intestinal digestibility; Microbial contamination; ${ }^{15} \mathrm{~N}$; Ensiling; Italian rye-grass

\section{Introduction}

The advance of protein rationing systems for ruminants needs accurate information about the supply of protein from the feeds, which is determined by their values of ruminal degradability and intestinal digestibility. The simplest method to estimate both parameters is by using in situ techniques. These combine the measurement of particle passage and feed degradation in the rumen to estimate the ruminal effective degradability (ED; Ørskov and McDonald, 1979) and both events together with measures of intestinal digestion to estimate the intestinal effective digestibility (IED; González et al., 1999). However, these techniques are subjected to some limitations (microbial contamination, transit model employed), and hence critical for forage evaluation. Moreover, taking into account that fibre is the main substrate for microbial attachment, the estimation of ED and IED in forages is under large experimental error because of the microbial contamination by adherent microorganisms of rumen incubated residues (Michalet-Doreau and Ould-Bah, 1989; Rodríguez et al., 1999a). As reported by Rodríguez et al. (1999a), the under-evaluation of crude protein (CP) ED derived from the microbial contamination increases with the cellulose content and decreases with the concentration of CP in the feed. Therefore, this error may vary with preservation treatments of forages through the associated changes in the chemical composition. On the other hand, values of ED are commonly estimated considering only the fractional outflow rate of small particles from the rumen. However, the process that leads to size reduction and to the increase in particle density implies an additional rumen residence time and consequently an increase of the ED estimates (González et al., 2006a). The importance to consider also the rate of conminution and mixing of particles to obtain more reliable ED estimates was underlined by the ARC (1984), but even after 20 years this approach is rarely employed.

The utilisation of silages is increasing in ruminant diets because it is more practical and easy to use silages than green forages, especially in unifeed diets. However, the knowledge on the microbial colonisation of silages and on the effects of this preservation treatment 
on the forage protein value is still inadequate. It is generally accepted that proteins from silages have a higher ED than those of their original green forages as a consequence of the previous degradative actions of the ensiling flora. However, in some works (Gómez, 1998) a low degradation rate for the insoluble proteins of silages had been also observed, which may be associated with the denaturalisation of proteins by the acidity generated during the ensiling process.

In the present study, a sample of Italian rye-grass was employed as a model of temperate grass to determine: (i) the effect of ensiling on the particle microbial colonisation, the ruminal degradability and the intestinal digestibility of protein and (ii) the effect of the microbial contamination on the accuracy of the degradability estimates. Two models of transit-degradation, one based in the use of only the outflow rate of particles from the rumen, and other using this rate together with that derived of their conminution and mixing in this compartment, were also considered.

\section{Materials and methods}

\subsection{Tested forages}

A sample of Italian rye-grass collected at tall state was studied together with its silage, obtained, after pre-haymaking, in a trench silo. Both samples were obtained in a farm of the Asturias region (north of Spain). These samples were freeze-dried and ground to pass a $2 \mathrm{~mm}$ screen for in situ studies and to pass $1 \mathrm{~mm}$ screen for chemical composition analysis (Table 1).

\subsection{Animals and feeding}

Three wethers fistulated with rumen and "T" duodenal simple cannulae were used. The animals were housed in metabolism cages inside a local with atmosphere controlled and fed with a mixed diet of Italian rye-grass silage, corn silage and concentrate (1:1:1 on DM).

Table 1

Chemical composition (g/kg DM) of green (GRG) and ensiled (ERG) Italian rye-grass

\begin{tabular}{lcc}
\hline Item & GRG $^{\mathrm{a}}$ & ERG \\
\hline Dry matter & 299 & 225 \\
Organic matter & 911 & 886 \\
Crude protein & 96.8 & 123 \\
Total analysed amino acids & 72.2 & 62.7 \\
Neutral detergent fibre & 534 & 608 \\
Acid detergent fibre & 310 & 379 \\
Lignin (sa) & 20.8 & 30.1 \\
NDIN & 2.17 & 1.61 \\
ADIN & 0.58 & 0.98 \\
\hline a Pre-haymaked. & & \\
b NDIN: N insoluble in neutral detergent. & &
\end{tabular}


The concentrate contained (per kg DM) $192 \mathrm{~g} \mathrm{CP}$ and $297 \mathrm{~g}$ neutral detergent fibre (NDF). The same concentrations in the diet were $116 \mathrm{~g} \mathrm{CP}$ and $527 \mathrm{~g}$ NDF. This diet was offered, in six equal meals (at intervals of $4 \mathrm{~h}$ ), at a level of $40 \mathrm{~g} \mathrm{DM} / \mathrm{kg} \mathrm{BW}^{0.75}$, from 14 days before and throughout the experimental period.

\subsection{Experimental procedures}

On days 1-4 of the experimental period, the particle passage through the rumen of the ensiled Italian rye-grass included in the diet was measured. For this purpose, a pulse dose $(40 \mathrm{~g})$ of this forage labelled with europium $(\mathrm{Eu})$ was offered to each animal and normally consumed in 20 min immediately before the first daily meal. A total of 20 samples were obtained from the duodenal cannula, the first before supplying the marker and the remainder between 2 and $82 \mathrm{~h}$ afterwards. Previously, this forage had been marked by immersion with $10 \mathrm{~g} \mathrm{Eu} / \mathrm{kg}$ of food as described by González et al. (1998). These samples were dried, milled and analysed for Eu. The pattern of Eu concentrations in the duodenal digesta over time was described for each animal by fitting to the model of Dhanoa et al. (1985) and, as indicated by González et al. (2006a), primary and secondary rate constants of this model were assumed, respectively, as the rate of evacuation of particles out the rumen $\left(k_{\mathrm{p}}\right)$ and the rate of conminution and mixing of particles $\left(k_{\mathrm{c}}\right)$ for both tested forages.

In situ studies were carried out on days 5-17 of the experimental period. Bags of $11 \mathrm{~cm} \times 7 \mathrm{~cm}$ (inner dimensions) were made by heat-sealing (Preci-Pack P30N, Dover Pack S.A., Barcelona, Spain) from nylon cloth with a pore size of $46 \mu \mathrm{m}$ (Saatilon, SAATI Serigrafia Iberica S.A., Almazora, Castellón, Spain). The bags were filled with approximately $3 \mathrm{~g}$ (freeze-dried) of feed samples and incubated in the rumen of each animal for intervals of 2, 4, 8, 16, 24, 48 and $72 \mathrm{~h}$. Two series of incubation with duplicate bags were conducted for each feed. At each series of incubation, all bags were placed simultaneously in the rumen just before the wethers were offered their first meal of the morning. After collecting from the rumen, bags were washed with tap water and stored at $-20^{\circ} \mathrm{C}$. When thawed, the bags were washed three times for $5 \mathrm{~min}$ in a turbine washing machine. The same washing procedure was applied to two series of two bags of each feed to obtain the zero hours value. For each sheep and incubation time, one bag of each incubation series was stored at $-20{ }^{\circ} \mathrm{C}$, freeze-dried and destined to intestinal digestibility studies (see later). The other bag was dried in an oven for $48 \mathrm{~h}$ at $80^{\circ} \mathrm{C}$, analysed for DM, N, ${ }^{15} \mathrm{~N}$ abundance and amino acids and used to establish ruminal degradation parameters. Although ruminal degradation of amino acids was studied (non-published data), these results were only employed in this paper to estimate the ED of the total analysed amino acids (TAA), considering these values as representative of those of the true protein of the feeds.

To evaluate the microbial contamination of the rumen incubated residues the rumen micro-organism were labelled with a 98 atoms $\%$ enriched $\left({ }^{15} \mathrm{NH}_{4}\right)_{2} \mathrm{SO}_{4}$ solution $(102 \mathrm{mg}$ $\mathrm{N} / \mathrm{l}$ ), which was continuously infused into the rumen at a rate of $400 \mathrm{ml} / \mathrm{d}$ from the beginning of the experimental period to the end of these studies. At this moment, the rumen was manually emptied just before the first morning meal. The ruminal content was homogenized and a sample of solid adherent bacteria (SAB) was isolated from a $1.2 \mathrm{~kg}$ sample (fresh matter) of rumen digesta as indicated by Rodríguez et al. (2000). Samples of SAB were subjected to determinations of DM, N, ${ }^{15} \mathrm{~N}$ abundance and amino acids. 
The freeze-dried residues of rumen incubation of each tested forage were pooled for each incubation time and the resulting samples were analysed for DM and N. Six sub-samples of $0.2 \mathrm{~g}$ were taken from each pooled sample and placed in heat-sealed nylon bags of the above indicated material having an approximately round shape (diameter $3 \mathrm{~cm}$ ). After a resting period of 10 days after the rumen empty, two bags from each feed and for each rumen incubation time and three additional empty bags (used as blanks) were inserted using a spindle through the duodenal cannula into the small intestine of each animal. Eight bags were inserted at random, per sheep per day, at a rate of one bag every $15 \mathrm{~min}$. Once recovered from the faeces, the bags were washed with tap water and deep-frozen. After thawing, they were mechanically washed (as above indicated) and used intact for $\mathrm{N}$ analysis. Blanks containing a known weight of nylon were used to correct for the $\mathrm{N}$ content of the bags, prior to determine the apparent disappearance of undegraded DM or CP in the intestine.

\subsection{Calculations}

The proportions of microbial $\mathrm{N}$ or DM in the bag residues were determined from ${ }^{15} \mathrm{~N}$ abundance values as follows:

$$
\begin{aligned}
& \text { Microbial } \mathrm{N}=\frac{{ }^{15} \mathrm{~N} \text { in residue }-{ }^{15} \mathrm{~N} \text { in feed }}{{ }^{15} \mathrm{~N} \text { in } \mathrm{SAB}-{ }^{15} \mathrm{~N} \text { in feed }} \\
& \text { Microbial DM }=\text { Microbial } \mathrm{N} \times\left(\frac{\mathrm{N} \text { in residue }}{\mathrm{N} \text { in SAB }}\right)
\end{aligned}
$$

The ${ }^{15} \mathrm{~N}$ abundance in tested feeds was determined on the zero incubation residues because only the insoluble fraction is subjected to microbial contamination.

The evolution with the rumen incubation time $(t)$ of the microbial contamination of bag residues $(M)$, expressed as proportion of $\mathrm{DM}$ or $\mathrm{CP}$, was described for each animal by an exponential model (González et al., 1998):

$$
M=m\left(1-\mathrm{e}^{-f t}\right)
$$

In this model, the asymptotic value $m$ corresponds to the microbial component of the feed undegradable fraction, whereas, for DM, $f$ represents the rate of microbial accumulation on feed particles.

The evolution with the rumen incubation time $(t)$ of the apparent and corrected disappearance values $(p)$ of DM or CP from the incubated bags (including zero values) was described for each animal using the model exposed by Ørskov and McDonald (1979):

$$
p=a+b\left(1-\mathrm{e}^{-k_{\mathrm{d}} t}\right)
$$

In this model, the constants $a$ and $b$ represent, respectively, the soluble fraction and the non-soluble degradable component, which disappears at a constant fractional rate $k_{\mathrm{d}}$ per unit of time. The undegradable fraction $(r)$ was estimated as $1-(a+b)$. Values of ED were estimated considering only the fractional rate of particle evacuation from the rumen $\left(k_{\mathrm{p}}\right.$; $\left.\mathrm{ED}_{\mathrm{p}}\right)$ or this rate together with that derived of the conminution and mixing of particles $\left(k_{\mathrm{c}}\right.$; $\mathrm{ED}_{\mathrm{c}, \mathrm{p}}$ ). 
In accordance with Ørskov and McDonald (1979) and McDonald (cited by the ARC, 1984), $\mathrm{ED}_{\mathrm{p}}$ and $\mathrm{ED}_{\mathrm{c}, \mathrm{p}}$ may be calculated, respectively, by the expressions:

$$
\begin{aligned}
& \mathrm{ED}_{\mathrm{p}}=a+b\left(\frac{k_{\mathrm{d}}}{k_{\mathrm{d}}+k_{\mathrm{p}}}\right) \\
& \mathrm{ED}_{\mathrm{c}, \mathrm{p}}=a+b\left(\frac{k_{\mathrm{d}}}{k_{\mathrm{d}}+k_{\mathrm{p}}}\right) \times\left(\frac{k_{\mathrm{d}}+k_{\mathrm{p}}+k_{\mathrm{c}}}{k_{\mathrm{d}}+k_{\mathrm{c}}}\right)
\end{aligned}
$$

The IED of DM and CP were estimated considering that intestinal disappearance values obtained at rumen incubation times of $0,2,4,8,16,24,48$ and $72 \mathrm{~h}$ were representative for the feed rumen outflow (DM or CP) in the intervals up to times of 1, 3, 6, 12, 20, 36, 60 and $84 \mathrm{~h}$, respectively. The feed rumen outflow $(\varnothing)$ in these intervals was established considering only $k_{\mathrm{p}}$ by the equation indicated by González et al. (2003):

$$
\emptyset_{\text {until } t}=r\left(1-\mathrm{e}^{-k_{\mathrm{p}} t}\right)+\frac{b k_{\mathrm{p}}}{k_{\mathrm{d}}+k_{\mathrm{p}}}\left(1-\mathrm{e}^{-\left(k_{\mathrm{d}}+k_{\mathrm{p}}\right) t}\right)
$$

Finally, the flow proportion in each interval was used to weigh intestinal disappearance values to determine IED.

\subsection{Chemical analyses}

Samples of tested forages were analysed for DM by drying at $105^{\circ} \mathrm{C}$ for $24 \mathrm{~h}$ in an air-forced oven, and for ash and $\mathrm{CP}($ Kjeldahl $\mathrm{N} \times 6.25)$ according to methods 942.05 and 954.01, respectively, of AOAC (2000), as well as for NDF (assayed without sodium sulphide; Van Soest et al., 1991), acid detergent fibre (ADF) and lignin (sa) (Robertson and Van Soest, 1981). Results of both NDF and ADF analyses were expressed including the residual ash. Insoluble nitrogen in neutral detergent (NDIN) and in acid detergent (ADIN) solutions was determined by Kjeldahl analysis of the NDF and ADF residues, respectively. Rumen incubation residues and intestinal mobile nylon bags were also analysed for nitrogen by the Kjeldahl method. Nitrogen isotopic proportions in SAB and rumen incubated residues were analysed by isotope-ratio MS (VG Prism II IRMS; VS ISOTECH, Ches., UK) linked in series to a Dumas-style N analyser EA 1108 (Carlo Erba Instruments, Milan, Italy). Amino acids were analysed as indicated by González et al. (2006b) after acid hydrolysis direct or preceded by oxidation with formic acid and hydrogen peroxide. Therefore, the total analysed amino acid content did not include tryptophan. Samples of faeces collected for passage studies were analysed for Europium by atomic emission spectrometry as described by González et al. (1998).

\subsection{Statistical methods}

All the statistical analyses were performed using the Statistical Analysis System for Windows software, Version 6.12 (SAS Institute Inc., Cary, NC, USA). The different kinetics associated with the indicated models for the particle passage through the stomachs, the microbial contamination and the rumen degradation were fitted by an iterative least- 
squares procedure and best fit values were chosen using the procedure NLIN of the SAS software. Effects of the forage preservation on microbial contamination parameters were subjected to variance analyses using a simple complete block experimental design. Results of rumen degradation were studied by variance analysis with a split-plot arrangement of treatments. In this design, the type of value (apparent versus corrected; CP versus TAA) was the whole-plot, which was tested against the animal $\times$ value type interaction as error term, and forage preservation and its interaction with the type of value were the sub-plot treatments. The results of intestinal disappearance of each forage were analysed considering animals and rumen pre-incubation times as factors in the model. Then, forage preservation effects were studied on the values of IED by the above indicated complete block design.

\section{Results}

The chemical composition of the Italian rye-grass before and after the ensiling process is shown in Table 1. Mean values in SAB samples for the concentrations of CP and total analysed amino acids were 438 and $411 \mathrm{~g} / \mathrm{kg} \mathrm{DM}$, respectively.

The microbial contamination for DM and $\mathrm{CP}$ of both forages fitted increasing exponential curves. For $\mathrm{DM}$, the ensiling led to an increase $(\mathrm{P}=0.006)$ of the asymptotic values $(\mathrm{m})$ and to a decrease $(\mathrm{P}=0.030)$ of the $f$ fractional rate (Table 2$)$. The contamination with $\mathrm{CP}$ showed the same trend, although significance was only observed at $\mathrm{P}=0.080$ for the $m$ values (Table 2).

Effects of ensiling and correction for the microbial contamination on degradation kinetic parameters and ED of DM and $\mathrm{CP}$ are shown in Table 3. Means and standard errors (S.E.M.) for $k_{\mathrm{c}}$ and $k_{\mathrm{p}}$ values used to establish ED estimates were $0.181 \pm 0.0165$ and $0.0497 \pm 0.0113$ (per h), respectively. For both, DM and CP, the correction for the microbial contamination led to significant changes: a reduction of the $r$ fraction and increases of the $b$ fraction, its fractional degradation rate $\left(k_{\mathrm{d}}\right)$ and the ED estimates, with the exception of the $k_{\mathrm{d}}$ in DM which did not reach significance. In addition, a low increase $(\mathrm{P}=0.030)$ of the $\mathrm{DM}$ soluble fraction was also observed, without practical importance. Effects of ensiling on DM degradation were a reduction $(\mathrm{P}<0.001)$ of the soluble frac-

Table 2

Effects of ensiling on the evolution with the rumen incubation time of the microbial contamination of the green (GRG) and ensiled (ERG) Italian rye-grass

\begin{tabular}{lllll}
\hline Item & GRG & ERG & S.E.M. & P \\
\hline Dry matter & & & & 0.006 \\
$\quad m$ & 0.126 & 0.199 & 0.0038 & 0.030 \\
$f\left(\mathrm{~h}^{-1}\right)$ & 0.0618 & 0.0270 & 0.0043 & \\
Crude protein & & & & 0.080 \\
$\quad m$ & 0.745 & 0.870 & 0.0267 & 0.424 \\
$f\left(\mathrm{~h}^{-1}\right)$ & 0.0760 & 0.0657 & 0.0073 & \\
\hline
\end{tabular}

$m$ (as proportion) and $f$ are parameters of the equation: $M=m\left(1-\mathrm{e}^{-f t}\right)$. 
Table 3

Effects of ensiling and of the correction for the microbial contamination on the ruminal degradation of dry matter and crude protein of the green (GRG) and ensiled (ERG) Italian rye-grass ${ }^{\mathrm{a}}$

\begin{tabular}{|c|c|c|c|c|c|c|c|c|}
\hline \multirow[t]{2}{*}{ Item $^{b}$} & \multicolumn{2}{|c|}{ Apparent value } & \multicolumn{2}{|c|}{ Corrected value } & \multicolumn{2}{|c|}{$\begin{array}{l}\text { Contamination } \\
\text { correction }\end{array}$} & \multicolumn{2}{|l|}{ Ensiling } \\
\hline & GRG & ERG & GRG & ERG & S.E.M. & $\mathrm{P}$ & S.E.M. & $\mathrm{P}$ \\
\hline \multicolumn{9}{|l|}{ Dry matter } \\
\hline$a$ & 0.358 & 0.262 & 0.362 & 0.265 & 0.0005 & 0.030 & 0.0005 & $<0.001$ \\
\hline$b$ & 0.476 & 0.533 & 0.493 & 0.560 & 0.0009 & 0.003 & 0.0034 & 0.002 \\
\hline$r$ & 0.167 & 0.206 & 0.145 & 0.175 & 0.0008 & 0.002 & 0.0034 & 0.002 \\
\hline$k_{\mathrm{d}}\left(\mathrm{h}^{-1}\right)$ & 0.0499 & 0.0415 & 0.0541 & 0.0457 & 0.0012 & 0.136 & 0.0014 & 0.013 \\
\hline $\mathrm{ED}_{\mathrm{p}}$ & 0.598 & 0.506 & 0.620 & 0.535 & 0.0029 & 0.024 & 0.0039 & $<0.001$ \\
\hline $\mathrm{ED}_{\mathrm{c}, \mathrm{p}}$ & 0.649 & 0.559 & 0.673 & 0.594 & 0.0034 & 0.025 & 0.0046 & 0.002 \\
\hline \multicolumn{9}{|c|}{ Crude protein } \\
\hline$a$ & 0.550 & 0.697 & 0.554 & 0.706 & 0.0017 & 0.116 & 0.0046 & $<0.001$ \\
\hline$b$ & 0.311 & 0.170 & 0.414 & 0.274 & 0.0086 & 0.014 & 0.0030 & $<0.001$ \\
\hline$r$ & 0.139 & 0.133 & 0.0323 & 0.0196 & 0.0089 & 0.013 & 0.0073 & 0.421 \\
\hline$k_{\mathrm{d}}\left(\mathrm{h}^{-1}\right)$ & 0.0636 & 0.0504 & 0.0989 & 0.0773 & 0.0024 & 0.011 & 0.0112 & 0.333 \\
\hline $\mathrm{ED}_{\mathrm{p}}$ & 0.724 & 0.776 & 0.829 & 0.872 & 0.0047 & 0.004 & 0.0077 & 0.012 \\
\hline $\mathrm{ED}_{\mathrm{c}, \mathrm{p}}$ & 0.759 & 0.792 & 0.877 & 0.904 & 0.0055 & 0.005 & 0.0084 & 0.065 \\
\hline
\end{tabular}

${ }^{a}$ Values are proportions of total dry matter or crude protein.

b $a$, soluble fraction; $b$, non-soluble degradable fraction; $r$, undegradable fraction; $k_{\mathrm{d}}$, degradation rate; $\mathrm{ED}_{\mathrm{p}}$ and $E D_{c, p}$, effective degradability calculated using rumen passage rate and this rate together with that of particle comminution, respectively.

tion and an increase $(\mathrm{P}=0.002)$ of the insoluble fractions as well as a reduction $(\mathrm{P}=0.013)$ of the degradation rate. The final result of all these changes was a large reduction of $\mathrm{ED}_{\mathrm{p}}(14.5 \%$ as average, $\mathrm{P}<0.001)$ and $\mathrm{ED}_{\mathrm{c}, \mathrm{p}}(12.8 \%$ as average, $\mathrm{P}=0.002)$. The ensiling led to an increase of the soluble $\mathrm{CP}$ at the expense of a similar reduction of the $b$ fraction $(\mathrm{P}<0.001)$. The degradation rate showed also an apparent reduction with ensiling (22.3\% as average). As a result of the opposite changes recorded for the availability of the $a$ and $b$ fractions, the ensiling slightly increased $\operatorname{ED}_{\mathrm{p}}(\mathrm{P}=0.012)$ and $\mathrm{ED}_{\mathrm{c}, \mathrm{p}}(\mathrm{P}=0.065)$ estimates.

The corrected values of the degradation kinetics of TAA showed differences with those of CP for all fractions (Table 4). Thus, TAA showed a lower solubility $(\mathrm{P}=0.001)$ than $\mathrm{CP}$ and inversely a higher potentially degradable fraction $(\mathrm{P}=0.003)$. A lower undegradable fraction for TAA was also observed $(\mathrm{P}=0.074)$. A faster degradation rate was also apparently observed for CP. As a consequence of these changes, $\mathrm{ED}_{\mathrm{p}}$ and $\mathrm{ED}_{\mathrm{c}, \mathrm{p}}$ estimates were similar for CP and TAA. Effects of ensiling recorded in this analysis of variance were similar to those above described from apparent and corrected values of CP. In addition, an interaction $(\mathrm{P}=0.018)$ was observed for the $a$ fraction in this analysis.

The increase of the time of rumen exposure of feed particles produced a reduction of $\mathrm{DM}$ intestinal disappearance (Table 5), for GRG $(\mathrm{P}<0.001)$ as well as for ERG $(\mathrm{P}=0.052)$. On the contrary, no effect was observed for the intestinal disappearance of $\mathrm{CP}$, being these last values variable and erratic. The results of IED showed a reduction of the intestinal availability with ensiling for both DM (0.130 v. 0.0962; S.E.M. $=0.0011 ; \mathrm{P}=0.012)$ and CP (0.522 v. 0.379; S.E.M. $=0.0114 ; \mathrm{P}=0.002$ ). 
Table 4

Comparison of ruminal degradation of crude protein and true protein (total analysed amino acids) in the green (GRG) and ensiled (ERG) Italian rye-grass ${ }^{\mathrm{a}}$

\begin{tabular}{|c|c|c|c|c|c|c|c|c|}
\hline \multirow[t]{2}{*}{ Item $^{\mathrm{b}}$} & \multicolumn{2}{|c|}{ Crude protein } & \multicolumn{2}{|c|}{ True protein } & \multicolumn{2}{|c|}{$\begin{array}{l}\text { Effect of protein } \\
\text { fraction }\end{array}$} & \multicolumn{2}{|c|}{ Effect of ensiling } \\
\hline & GRG & ERG & GRG & ERG & S.E.M. & $\mathrm{P}$ & S.E.M. & $\mathrm{P}$ \\
\hline$\overline{a^{1}}$ & 0.554 & 0.706 & 0.421 & 0.607 & 0.0030 & 0.001 & 0.0031 & $<0.001$ \\
\hline$b$ & 0.414 & 0.274 & 0.562 & 0.389 & 0.0051 & 0.003 & 0.0054 & $<0.001$ \\
\hline$r$ & 0.0323 & 0.0196 & 0.0170 & 0.0040 & 0.0031 & 0.074 & 0.0050 & 0.143 \\
\hline$k_{\mathrm{d}}\left(\mathrm{h}^{-1}\right)$ & 0.0989 & 0.0773 & 0.118 & 0.0895 & 0.0068 & 0.248 & 0.0099 & 0.149 \\
\hline $\mathrm{ED}_{\mathrm{p}}$ & 0.829 & 0.872 & 0.813 & 0.858 & 0.0091 & 0.372 & 0.0070 & 0.011 \\
\hline $\mathrm{ED}_{\mathrm{c}, \mathrm{p}}$ & 0.877 & 0.904 & 0.878 & 0.904 & 0.0093 & 0.988 & 0.0061 & 0.038 \\
\hline
\end{tabular}

${ }^{a}$ Values are corrected by microbial contamination and expressed as proportions of total crude protein or true protein.

${ }^{\mathrm{b}} a$, soluble fraction; $b$, non-soluble degradable fraction; $r$, undegradable fraction; $k_{\mathrm{d}}$, degradation rate; $\mathrm{ED}_{\mathrm{p}}$ and $\mathrm{ED}_{\mathrm{c}, \mathrm{p}}$ effective degradability calculated using rumen passage rate and this rate together with that of particle comminution, respectively.

${ }^{1}$ Significant protein fraction $\times$ ensiling interaction: S.E.M. $=0.0043 ; \mathrm{P}=0.018$.

Table 5

Effect of rumen incubation time on intestinal disappearance of the undegraded fraction of dry matter and crude protein of green (GRG) and ensiled Italian rye-grass (ERG)

\begin{tabular}{|c|c|c|c|c|}
\hline \multirow[t]{2}{*}{ Rumen incubation (h) } & \multicolumn{2}{|l|}{ Dry matter } & \multicolumn{2}{|c|}{ Crude protein } \\
\hline & GRG & ERG & GRG & ERG \\
\hline 0 & $0.160^{\mathrm{a}, \mathrm{b}}$ & 0.140 & 0.569 & 0.286 \\
\hline 2 & $0.185^{\mathrm{a}}$ & 0.105 & 0.502 & 0.255 \\
\hline 4 & $0.144^{\mathrm{b}, \mathrm{c}}$ & 0.100 & 0.518 & 0.324 \\
\hline 8 & $0.130^{\mathrm{b}, \mathrm{c}, \mathrm{d}}$ & 0.117 & 0.529 & 0.377 \\
\hline 16 & $0.097^{\mathrm{d}, \mathrm{e}}$ & 0.110 & 0.575 & 0.474 \\
\hline 24 & $0.107^{\mathrm{c}, \mathrm{d}, \mathrm{e}}$ & 0.061 & 0.460 & 0.396 \\
\hline 48 & $0.096^{\mathrm{d}, \mathrm{e}}$ & 0.098 & 0.482 & 0.477 \\
\hline 72 & $0.079^{\mathrm{e}}$ & 0.102 & 0.539 & 0.461 \\
\hline S.E.M. & 0.0127 & 0.0132 & 0.0636 & 0.0605 \\
\hline $\mathrm{P}$ & $<0.001$ & 0.052 & 0.889 & 0.136 \\
\hline
\end{tabular}

Values with different superscripts (a-e) in the same column are significant at $\mathrm{P}<0.05$.

\section{Discussion}

The chemical composition of green and ensiled samples were as expected. Thus, the high DM content of the green forage at ensiling $(299 \mathrm{~g} / \mathrm{kg})$ should prevent the effluent losses. Therefore, the losses during the forage preservation process should be limited to those of cellular respiration and microbial fermentation, mainly based in the oxidation of soluble carbohydrates. Consequently, the water generated in these oxidations led to a decrease of the DM content, whereas the disappearance of soluble carbohydrates induced a passive increase of the other components: minerals (as showed by the reduction of the OM content), fibre fractions (especially ADF in this work) and CP. The increase of CP was associated, however, 
with a reduction of the amino acid content, as a consequence of the protein fermentation, and with a large increase in the ADIN proportion. All these changes reduced the nutritive value of the forage.

The exponential evolution of the microbial contamination along the rumen residence time (expressed in terms of DM or CP) was in agreement with previous results obtained in different feeds (González et al., 1998; Rodríguez et al., 1999b). The higher asymptotic value $(m)$ observed for DM when ensiling reflects a higher level of colonisation, which is in agreement with the increase of fibre fractions produced when ensiling. MichaletDoreau and Ould-Bah (1989) and Rodríguez et al. (1999a) indicated the content of NDF and cellulose, respectively, as the main factor determining the microbial contamination of feeds. However, ensiling also led to a reduction of the microorganism accumulation rate on the feed particles. There are several possible explanations behind the observed slower colonisation. The diminished concentration of fermentable nutrient in particles, their high content in organic acids (which may have toxic effects for the microorganisms) or a higher degradation resistance of the substrate (as showed by the results of the fractional degradation rate of $\mathrm{DM}$ ) which implies a lower supply of nutrients for the development of micro-colonies. The same trend between GRG and ERG was also observed for CP microbial contamination. The high proportions attained for this contamination ( 0.745 and 0.870 , respectively) evidence the need of this correction to obtain a reliable in situ evaluation in forages.

The effects of removing the microbial contamination of rumen incubated residues on the kinetic degradation parameters agreed well with mathematic predictions. Thus, the undegradable fraction was reduced together with an increase of the potentially degradable fraction and of its degradation rate. Initially, the soluble fraction should not be affected. However, this estimate is obtained in our experiment by the intersection of this kinetic with the ordinate axis, and, therefore, may be affected by the above indicated changes. Within these errors, the higher was for the undegradable fraction. Therefore, the apparent estimations of the undegradable CP in grasses are mainly composed by adherent microorganisms. Large errors were also observed for ED apparent estimates of CP, which underevaluated $\mathrm{ED}_{\mathrm{p}}$ (12.7 and $11.0 \%$ for GRG and $\mathrm{ERG}$, respectively) and $\mathrm{ED}_{\mathrm{c}, \mathrm{p}}$ (13.5 and $12.4 \%$ for GRG and ERG, respectively) truly values. However, the associated errors on the undegraded CP were increased by three and four-fold. Thus, the apparent estimates of the undegraded $\mathrm{CP}$ derived from $\mathrm{ED}_{\mathrm{p}}$ and $\mathrm{ED}_{\mathrm{c}, \mathrm{p}}$ values would include a proportion of microbial CP of 0.380 and 0.490 for GRG and 0.429 and 0.538 for ERG. Consequently, the use of non-corrected values for forage evaluation represents a partial duplication of the microbial CP component of the rumen flow and, therefore, a large error in the calculation of the protein supply to the duodenum.

Effects of ensiling on DM degradation were in agreement with the disappearance of soluble carbohydrates during silage maturing and the associated passive increase of fibre fractions. In particular, the increase of ADIN with ensiling will support the increase recorded for the undegradable fraction of DM. The increase of ADIN evidences the occurrence of reactions between carbohydrates and proteins as well as of partial or total Maillard reactions (Van Soest, 1982). The reduction of the fractional degradation rate was in agreement with the slower colonisation of the silage above indicated as well as with its higher content of ADIN. The final result of all these changes was a large reduction of the ED values, which agrees with the indication of a lower nutritive value observed from the changes 
in chemical composition. Assuming a similar ED for OM and DM, it can be stated that ensiling markedly reduced the microbial protein synthesis promoted by this forage in the rumen. This is a consequence of the reduction of: (i) the forage OM concentration and its fermentation in the rumen and (ii) the efficiency of the microbial protein synthesis, due to the OM pre-fermentation (ARC, 1984) and the increased proportion of fermentable OM from protein (NRC, 2001).

The degradative actions of microorganisms during ensiling partially affected the insoluble CP or TAA as depicted by the $b$ fraction reductions (Tables 3 and 4). However, ensiling did not increase the $r$ fraction, which gives evidence that the above indicated condensation reactions should not be complete. The apparent $k_{\mathrm{d}}$ reductions after ensiling (around 21 and $24 \%$ for CP and TAA, respectively) seem to indicate a higher resistance to the microbial degradation. This may be a consequence of insoluble protein denaturalisation by the acids generated during forage biomass fermentative processes. A reduction of the degradation rate has been observed in experiments protecting proteins with acids (Arroyo et al., 2005; Ouarti et al., 2006). Effects of ensiling on protein degradability were opposite: an increase as a consequence of the higher soluble fractions and a decrease by the lower insoluble degradable fractions, which is reinforced by the apparent reduction of $k_{\mathrm{d}}$ values. As a result of this compensation, the ensiling only led to a low increase of the ED values. Thus, for both $\mathrm{CP}$ and TAA and considering the corrected values, this increase only represents $5 \%$ for $\mathrm{ED}_{\mathrm{p}}$ and $3 \%$ for $\mathrm{ED}_{\mathrm{c}, \mathrm{p}}$.

Compared to CP, the lower solubility (estimated from the $a$ values) observed in true protein (Table 4) can be attributed to the higher solubility of the non-protein nitrogen feed compounds (amines, amides, ammonium salts, nucleic acids, etc.) included in CP. This effect was associated with a higher insoluble degradable fraction in true protein than in $\mathrm{CP}$, as both fractions were practically complementary due to the very small values of the undegradable fraction. Degradation rate values also showed a high apparent increase for TAA. This fact was also observed for soybean meal by González et al. (2000), who associated it with the nitrogenous compounds bounded to the fibre fraction. These compounds will be slowly degraded and, when they are proteins, they could be resistant to the hydrolysis and therefore not detected in the chromatographic analysis. As a consequence of the changes observed, the degradability estimates of CP and TAA were similar, especially for the $\mathrm{ED}_{\mathrm{c}, \mathrm{p}}$ values. Although this similarity seem to indicate that true protein evaluation can be derived from $\mathrm{CP}$ degradability estimates with an acceptable degree of accuracy, the indicated differences for degradation kinetics show the need of more extended studies on this subject.

The irregular evolution of intestinal disappearance values with the rumen residence time in both forages is not consistent with the progressive reduction reported in others forages (Faría-Mármol et al., 2002; González et al., 2001) as a consequence of the progressive enrichment of feed particles in indigestible compounds with the extent of rumen degradation. This may be a consequence of the high and accumulative microbial contamination in the rumen. Thus, irregular variations were more marked for CP than for DM and in ERG than in GRG in agreement with the importance of the contamination observed. Therefore, to obtain accurate intestinal digestibility values in grass forages it is necessary to determine this contamination before and after the intestinal incubation of the samples, which implies a supplementary complexity in this technique. This irregular evolution prevented the use of the mathematical method proposed by González et al. (1999) to estimate the IED. On 
the contrary, the method proposed in this study allows these estimations when intestinal disappearance values cannot be fitted to a mathematical equation. Our results of IED for CP are lower than those indicated by Vérité et al. (1987) and NRC (2001) for both green (0.75) and ensiled (0.60) grasses. In addition, these results are over-evaluated as a consequence of the high contamination with microbial $\mathrm{CP}$ of these samples. Considering this contamination as well as a value of intestinal digestibility of 0.80 for bacterial CP (Vérité et al., 1987), the $\mathrm{CP}$ digestibility in the intestine will be of 0.351 and 0.0563 for GRG and ERG, respectively. This simulation shows the need to correct also the microbial contamination in intestinal digestibility studies for an accurate feed protein evaluation by in situ methods. It also shows a low intestinal digestibility of protein in this kind of forages, especially in silages. The negative effect of ensiling on the intestinal digestibility of $\mathrm{CP}$ may be a consequence of the large reduction of the $\mathrm{CP}$ insoluble fraction leading to a passive increase of indigestible nitrogen compounds in the total $\mathrm{CP}$ of forage particles. The increase of the ADIN content with ensiling should also contribute to this effect.

\section{Conclusions}

The low values of rumen undegraded protein and its intestinal digestibility show that the protein value in these forages is mainly determined by their potential for microbial protein synthesis. Ensiling decreases the protein value of this type of forages by reducting both rumen fermentable energy supply and the content of intestinal digestible protein. The correction of the microbial contamination for ruminal degradability as well as for intestinal digestibility is necessary for an accurate in situ feed evaluation.

\section{Acknowledgements}

This work was supported by the CICYT funded Projects AGF 1998-0842. Analyses of ${ }^{15} \mathrm{~N}$ isotopic ratios were performed at the Servicio Interdepartamental de Investigación, Universidad Autónoma de Madrid.

\section{References}

AOAC, 2000. Official Methods of Analysis, 17th ed. Association of Official Analytical Chemists, Gaithersburg, MD.

ARC, 1984. The nutrient requirement of ruminant livestock. Supplement 1. Report of the protein group of the ARC Working Party on the nutrient requirement of ruminants. Commonwealth Agricultural Bureaux, Bruxeles, Belgium.

Arroyo, J.M., González, J., Alvir, M.R., Rodríguez, C.A., Ouarti, M., 2005. Protección frente a la degradación ruminal de la harina de girasol mediante el tratamiento con ácidos y calor. Información Técnica Económica Agraria 26 (Suppl.), 542-544.

Dhanoa, M.S., Siddons, R.C., France, J., Gale, L., 1985. A multicompartmental model to describe marker excretion patterns in ruminant faeces. Br. J. Nutr. 53, 663-671.

Faría-Mármol, J., González, J., Rodríguez, C.A., Alvir, M.R., 2002. Effect of diet forage to concentrate ratio on rumen degradability and postruminal availability of protein from fresh and dried lucerne. Anim. Sci. 74, $337-345$. 
Gómez, G., 1998. Degradabilidad ruminal de los ensilados de hierba y maíz. Escuela Técnica Superior de Ingenieros Agrónomos, Universidad Politécnica, Madrid, Spain. Ph.D. Thesis. 329 pp.

González, J., Sánchez, L., Alvir, M.R., 1999. Estimation of intestinal digestibility of undegraded sunflower meal protein from nylon bag measurements A mathematical model. Reprod. Nutr. Dev. 39, 607-616.

González, J., Rodríguez, C.A., Andrés, S.G., Alvir, M.R., 1998. Rumen degradability and microbial contamination of fish meal and meat meal measured by the in situ technique. Anim. Feed Sci. Technol. 73, 71-84.

González, J., Rodríguez, C.A., Centeno, C., Lanrani, F., 2000. Rumen effective degradability of amino acids from soybean meal corrected for microbial contamination. Reprod. Nutr. Dev. 40, 579-586.

González, J., Faría-Mármol, J., Rodríguez, C.A., Alvir, M.R., 2001. Effects of stage of harvest on the protein value for ruminants of fresh lucerne. Reprod. Nutr. Dev. 41, 381-392.

González, J., Ouarti, M., Rodríguez, C.A., Alvir, M.R., 2006a. Effects of considering the rate of comminution of particles and microbial contamination on the accuracy of in situ studies of feed protein degradability in ruminants. Anim. Feed Sci. Technol. 125, 89-98.

González, J., Faría-Mármol, J., Matesanz, B., Rodríguez, C.A., Alvir, M.R., 2003. In situ intestinal digestibility of dry matter and crude protein of cereal grains and rapeseed in sheep. Reprod. Nutr. Dev. 43, 29-40.

González, J., Faría-Mármol, J., Rodríguez, C.A., Ouarti, M., Alvir, M.R., Centeno, C., 2006b. Protein value for ruminants of a sample of whole cotton seed. Anim. Sci. 82, 75-81.

Michalet-Doreau, B., Ould-Bah, M.Y., 1989. Estimation of the extent of bacterial contamination in bag residues and its influence on in sacco measurements of forage nitrogen degradation in rumen. In: Asociation Française Production Fourragère (Ed.), Proceedings of the XVIth International Grassland Congress, Nice, France, pp. 909-910.

NRC, 2001. Nutrient Requirements of Dairy Cattle, seventh revised ed. National Academy Press, Washington DC, USA.

Ørskov, E.R., McDonald, I., 1979. The estimation of protein degradability in the rumen from incubation measurements weighted according to rate of passage. J. Agric. Sci. Camb. 92, 499-503.

Ouarti, M., González, J., Fernandes, L.F.J., Alvir, M.R., Rodríguez, C.A., 2006. Protection of protein from soybean meal by treatments with malic acid solutions and heat. Anim. Res. 55, 165-175.

Robertson, J.B., Van Soest, P.J., 1981. The detergent system of analysis and its application to human foods. In: James, W.P.T, Theander, O. (Eds.), The Analysis of Dietary Fibre in Food. Marcel Dekker, New York, NY, USA, pp. 123-158.

Rodríguez, C.A., González, J., Alvir, M.R., Cajarville, C., 1999a. Underestimation of in situ effective degradability of $\mathrm{N}$ due to microbial contamination. In: Lobley, G.E., White, A., MacRae, J.C. (Eds.), Protein Metabolism and Nutrition. Book of Abstracts of the VIIIth International Symposium on Protein Metabolism and Nutrition. Wageningen Pers, Wageningen, Netherlands, p. 68.

Rodríguez, C.A., González, J., Alvir, M.R., Repetto, J.L., 1999b. Microbial nitrogen contamination of in sacco ruminal incubated feeds. In: Lobley, G.E., White, A., MacRae, J.C. (Eds.), Protein Metabolism and Nutrition. Book of Abstracts of the VIIIth International Symposium on Protein Metabolism and Nutrition. Wageningen Pers, Wageningen, Netherlands, p. 69.

Rodríguez, C.A., González, J., Alvir, M.R., Centeno, C., Lamrani, F., 2000. Composition of bacteria harvested from the liquid and solid fractions of the rumen of sheep as influenced by intake level. Br. J. Nutr. 84, 369-376.

Van Soest, P.J., 1982. Nutritional Ecology of the Ruminant, second ed. Cornell University Press, Ithaca, USA.

Van Soest, P.J., Robertson, J.B., Lewis, B.A., 1991. Methods for dietary fiber, neutral detergent fiber and nonstarch polysaccharides in relation to animal nutrition. J. Dairy Sci. 74, 3583-3597.

Vérité, T., Chapoutot, P., Michalet-Doreau, B., Peyraud, J.L., Poncet, C., 1987. Révision du système des protéines digestibles dans l'intestin (PDI), Bull. Techn. CRZV, Theix. INRA 70, 19-34. 